\title{
Santali Language
}

National Cancer Institute

\section{Source}

National Cancer Institute. Santali Language. NCI Thesaurus. Code C154108.

An Austroasiatic language spoken mainly in the Indian states of Jharkhand, West Bengal, and Chhattisgarh. 